\title{
Santa Casa de Misericórdia, Hospício São Pedro e loucura: notas sobre os primórdios da psiquiatria em Porto Alegre
}

\author{
Santa Casa de Misericórdia, Hospício São Pedro and madness: notes on the \\ origins of psychiatry in Porto Alegre
}

\section{Luís Guilherme Streb}

Conselho Editorial, Rev Psiquiatr RS. Doutor em Medicina, Universidade Livre de Berlim.

Asylo de alienados de ambos os sexos
O asylo continua repleto de alienados de ambos os sexos e se maior fosse não chegaria para tantos
infelizes, pois de todas as partes da provincia se reclama entrada denovos.
É este o maior onus que peza sobre a Santa Casa, tão desprotegida e abandonada a seus escassos
recursos, cuja receita repito, já não alcança ás avultadas despezas que éobrigada a fazer.
Estes pensionistas vitalicios, são os mais pezados para o pio estabelecimento pelas despezas que fazem, e
o incomodo que dão.
As roupas que estragão todos os annos e os utencilios que destroem, bem caro custão, sem que aquelles
que os atirão no asylo jámis procurem por elles, nem tratem ao menos de mandar-lhes com que cubrão o corpo,
e se não encontrassem a caridade deste pio estabelecimento da capital da provincia, vagarião cobertos de
andrajos pelos lugares de onde vierão; porém a Divina Providência a quem a Santa Casa so deve sua
conservação vella por elles, e pelos indigentes que procurão por este pio estabelecimento aonde encotrarão
linitivo ás suas dores e a seus males.
Os ditos dois asylos não poderão ter outro melhoramento senão a manutenção da mais rigorosa limpeza
quotidiana, e as caiaçóes necessárias para corresponder a esse anseio, não obstante estarem estes infelizes que
nem os seus próprios parentes os procurão, fora do alcance das vistas dos curiosos e indiscretos, não só no dia
da visitação como todo o anno.
Existião até o fim do anno de 1871,38 alienados de ambos os sexos, que com 60 que entrarão no anno
findo prefaz ototal de 98 . Sahirão curados 8 homens e 1 mulher. Falecerão 3 homens e 1 mulher. Ficão existindo
23 homens e 24 mulheres. Total 47, sendo particulares.
As antigas reclusões do pavimento térreo estão occupadas com alienados immundos.
Capella do Senhor dos Passos

As imagens da capa, de material que fotografei no Centro de Documentação e Pesquisa da Santa Casa, pretendem levar adiante a idéia do Conselho Editorial da Revista de ampliar a perspectiva que temos da história da psiquiatria no estado, sem deixar de lançar nossos olhos para o futuro, como demonstra o conteúdo desta edição*.

Não há documentação clínica anterior ao Hospício São Pedro, inaugurado em junho de 1884; as fotos ilustram partes do Livro de Entradas e de relatórios

\footnotetext{
* Agradeço em especial a Adriane Raimann, pelo seu auxílio com o material do Centro de Documentação e Pesquisa da Santa Casa de Misericórdia, Porto Alegre, RS.
}

anuais da Provedoria da Santa Casa, disponíveis desde o ano de 1839. O texto fotografado acima é parte do relatório do ano de 1872, escrito pelo provedor, o general Lima e Silva. Como se vê, a situação naquela época era muito difícil; faltavam recursos, muitas pessoas já eram “vitalícias”, abandonadas pala família. Havia 47 alienados, os “immundos” ocupando reclusões do térreo. Desta descrição, percebe-se a necessidade de outro espaço, mais adequado, para o cuidado destes “infelizes”. Estes relatórios são a principal fonte de informação sobre a medicina da época em Porto Alegre e sobre o processo que levou à fundação do Hospital São Pedro e, com isto, ao nascimento da psiquiatria entre nós. Percebe-se uma situação difícil no amparo aos 
doentes, sem qualquer menção a tratamento médico; na verdade, as “Misericórdias” procuravam dar assistência à miséria, mais do que tratar medicamente. Nesta época, havia dois médicos atendendo as 850 pessoas internadas, que recebiam assistência principalmente de religiosas e enfermeiros.

Os pacientes eram distribuídos pelas enfermarias segundo critérios sociais (renda, por exemplo) e comportamentais (loucos furiosos ou não-furiosos, imundos ou não-imundos). Muitos eram recolhidos nas ruas ou levados pela polícia.

A partir deste material, pode-se tentar reconstruir os primórdios da nossa especialidade aqui em Porto Alegre. Do Livro de Entradas, onde constam nome, motivo da baixa e tempo de internação, tem-se uma idéia das categorias diagnósticas usadas à época - como “congestão cerebral”, por exemplo -, tempos em que vigoravam os sistemas de Esquirol, com cinco grandes categorias (lipemania, monomania, mania, demência e idiotia), Falret (loucuras paralítica, circular, epiléptica, alcoólica e persecutória) e Morel (alienações hereditárias, por intoxicação, idiopáticas, simpáticas, nevroses e demência).

Dos relatórios, obtém-se a história da Santa Casa como albergue para os “doudos”, em suas celas no subsolo, e a necessidade de um lugar específico para eles, que daria origem ao movimento que construiu o Hospício São Pedro ${ }^{\dagger}$.

Com as primeiras faculdades de medicina do Brasil, fundadas em 1832 no Rio de Janeiro e em Salvador, o poder público passou a ser influenciado no sentido de organizar o atendimento da população e promover medidas de saúde pública. Em Porto Alegre, surgiu em 1847 um Código de Posturas, com orientações sanitárias e higiênicas: "A medicina assessorava o governo na organização da sociedade”

No começo da década de 1870, iniciou-se um movimento para retirar da Santa Casa os insanos e proporcionar a eles local e condições adequados de atendimento. O provedor José Antonio Coelho Junior foi a principal figura neste intento. Depois de muitas idas e vindas, dificuldades para conseguir recursos e local, o magnífico edifício na Estrada do Mato Grosso foi inaugurado em 1884. Seu primeiro diretor, Carlos Lisboa, médico de 25 anos formado no Rio de Janeiro, ex-interno no Hospício Pedro II, prestava contas à provedoria da Santa Casa e comandava as práticas terapêuticas do novo asilo, seguindo os preceitos da época: tratamentos físico, higiênico e moral. Morreu 4 anos depois. Seguiram-se na sua direção Ramiro Barcellos, Olinto de Oliveira, Francisco Dias de Castro, Tristão Torres e Deoclécio Pereira. Em 1926, assume Jacintho Godoy, e inicia-se, então, sob sua sábia orientação, a terceira e fundamental etapa de consolidação da psiquiatria no estado, que estendeu-se até os anos $60^{\S}$.

Creio que um dos motivos que nos levam a olhar para o passado é tentar vislumbrar como eram vistos e tratados os pacientes, numa tentativa de calibrar nossa capacidade e nossos esforços com aqueles que admiramos. Se temos mais recursos técnicos, pessoais e institucionais atualmente, é importante não esquecer que estamos também submetidos a circunstâncias sociais e econômicas que têm nos afastado dos pacientes, em atmosfera moldada por mentalidade vaidosamente materialista.

Neste sentido, “(...) não acreditem que a participação humana deva desaparecer quando começa a pesquisa científica. Grandes questões humanitárias devem ainda ser respondidas no campo da Psiquiatria; os grandes pensamentos vêm do coração; cabeça e mãos trabalharão melhor se mantivermos uma terna compaixão pelo sofrimento”. Estas palavras de Griesinger, proferidas mais ou menos à mesma época destes acontecimentos, poderiam ainda bem nos guiar nestes tempos em que muito se sabe sobre memória, mas pouco se lembra dos que nos precederam ${ }^{3}$.

\section{Referências}

1. Wadi YM. Palácio para guardar loucos: uma história das lutas pela construção do hospital de alienados e da psiquiatria no Rio Grande do Sul [dissertação]. Porto Alegre: UFRGS; 1996.

2. Godoy J. Psiquiatria no Rio Grande do Sul. Porto Alegre; 1955.

3. Griesinger W. Vortrag zur Eröffnung der psychiatrischen Klinik zu Berlin, am 2. Mai 1867. Eur Arch Psych Clin Neurosci. 1868;1(1):143-58.

\footnotetext{
† Essa história foi tema de interessante trabalho de mestrado, do qual esses dados foram retirados, de Yonissa Marmitt Wadi: "Palácio para guardar loucos: uma história das lutas pela construção do hospital de alienados e da psiquiatria no Rio Grande do Sul” (Programa de PósGraduação em História, Universidade Federal do Rio Grande do Sul, 1996). ${ }^{1}$

‡ Agradeço à colega Ana Luiza Wolf pela gentileza de fornecer um resumo da obra acima, do qual também foram usados alguns dados.
}

\footnotetext{
§ Fonte importante e imprescindível: Jacintho Godoy. Psiquiatria no Rio Grande do Sul (Porto Alegre, 1955). ${ }^{2}$
} 